\title{
Dear Joan
}

[From the Editors: We were so taken with the complimentary copies of Joan Kaywell's Dear Author: Letters of Hope we received at the ALAN Workshop, we asked noted YA scholar Teri Lesesne to write a review. Dr. Lesesne chose the innovative and highly appropriate format of a letter.]

January 2007

Dear Joan:

Thank you so much for your dedication to teens, especially those whose lives are not always the stuff of movies. You know, those kids who do not see a "happily ever after" in their lives because of all the troubles they face now. Those kids are often the nameless and marginalized. Their problems are all too often discounted by the adults that should care for them. You are their hope, you and your new book. Through the work on this book you proved once again how much you care for teens and how much you hold out hope to them so that they can continue to grow and become the successful adults inside of them all.

There have been so many teens in my life in my 30 years of teaching, teens that face some of the same issues tackled by the incredibly talented authors in your book, Dear Author: Letters of Hope. I wept as I read the letter from "Debbie" to Laurie Halse Anderson in which she talked about her own fear of men stemming from her rape when she was a freshman (much like Melinda in Speak). But then to read the powerful words of Anderson in response to the letter from Debbie moved me beyond tears. Here is an author writing about the power we all have, the GIFT that keeps the spark of our humanity alive in us even after disastrous things happen that are out of our control.

Every one of the letters from readers and every one of the heartfelt responses from these gifted and giving authors will speak volumes to those who work day in and day out with kids. In this time of No Child Left Behind, you are truly accomplishing that statement. With Dear Author: Letters of Hope you are ensuring that all those voices are heard: the voices of the bullied and tormented, the voices of those who may be about to give up hope that anyone cares about them.

Thank you, Joan, for bringing together this luminous group of authors including Christopher Paul Curtis, Chris Crutcher, Ellen Wittlinger, and Joan Bauer. Thank you on behalf of all those teens out there who believe no one could possibly know what they are experiencing. Thank you for showing them the power of words and books and reading in the healing process. May this book reach all those who hold out hope to their students.

Sincerely,

Teri

P.S. Dear Author is available from Philomel. 